\title{
KARAKTER MORFOLOGIS DAN PERKEMBANGAN ANATOMIS BIJI MELINJO (Gnetum gnemon L.)
}

\author{
Kandida Prajnaparamita", Siti Susanti' \\ Email: sitisusantibio@ugm.ac.id \\ ${ }^{122}$ Program Studi Biologi, Fakultas Biologi, Universitas Gadjah Mada
}

\begin{abstract}
Melinjo seeds (Gnetum gnemon L.) have many benefits, that it is necessary to know its morphological and anatomical characters. This study aimed to determine differences in morphological characters and anatomical development of melinjo seeds at four seed maturity stages. The morphological observation was carried out based on the quantitative and organoleptic characteristics of the melinjo seeds: outer envelope, size, and the color of the middle envelope. Seed development was anatomically observed in slides prepared with a non-embedding method using a sliding microtome then observed through a microscope. The outer seed envelope has a green to blackish-red color in the final stage, while the seed middle envelope has a light-brown to dark-brown in the final stage. The inner seed envelope is thin, non-rigid, and attached on the outside of the endosperm. The seeds' length ranges from $\pm 1,5 \mathrm{~cm}$ until $\pm 2,25 \mathrm{~cm}$ at the end-stage; seeds width are $1 \mathrm{~cm}-1,18 \mathrm{~cm}$; seeds diameter are 1 $\mathrm{cm}-1,16 \mathrm{~cm}$. The anatomical development showed tissue thickening and differentiation. The middle envelope is getting thicker: $318,84 \mu \mathrm{m}$ to $397,29 \mu \mathrm{m}$. Endosperm tissue cells undergo cell compaction as the seeds ripen. At the same time, embryonic tissue differentiation forms hypocotyl, epicotyl, and cotyledon.
\end{abstract}

Keywords: melinjo, seed, morphological, anatomical, embryo

\section{PENDAHULUAN}

Gnetum gnemon L. merupakan tanaman yang memiliki potensi pertanian tinggi di daerah Asia Tenggara dan Malaysia. Tanaman asli Indonesia ini memiliki tinggi hingga 15 meter (50 ft) dan dapat ditemukan di daerah kering hingga lembab. Spesies ini merupakan jenis tanaman yang tahan terhadap naungan kanopi atau disebut dengan shade-tolerant, tetapi umumnya ditanam di daerah terbuka dan memiliki ketahanan terhadap berbagai rentang suhu, curah hujan, serta mampu bertahan terhadap tanah yang kurang subur (Elevitch, 2006). G. gnemon L. atau biasa disebut melinjo, umumnya ditemukan di tepi aliran sungai, baik melinjo yang tumbuh secara liar maupun melinjo yang dibudidayakan. Disamping itu, tumbuhan ini mudah berkembang di dataran rendah dengan berbagai jenis tanah (Lim, 2012).

Melinjo merupakan tumbuhan yang dapat tumbuh sepanjang tahun atau disebut dengan tumbuhan perennial (Barua et al., 2015). Pohon melinjo yang selalu hijau sepanjang tahun menyebabkan bagian-bagiannya, seperti daun, bunga, biji, dan batangnya selalu tersedia di alam sehingga banyak dimanfaatkan bagian- bagiannya oleh masyarakat lokal. Buah melinjo yang telah matang diciri-cirikan dengan warna merah oranye, berdaging, dan mengandung getah. Pemanfaatan tumbuhan ini antara lain dari bagian buah, biji, daun, bunga, dan batangnya. Daun muda yang disebut dengan "so", bunga yang disebut dengan "kroto", dan kulit biji tua dapat digunakan sebagai bahan 
sayuran yang cukup populer di kalangan masyarakat (Nursamsi et al., 2017). Bagian tersebut banyak digunakan sebagai bahan makanan dan masakan, obat, dan komoditas lain. Disamping itu, kulit biji melinjo juga dapat dimanfaatkan sebagai pewarna alami dan dijadikan tepung kulit melinjo (Wahyuni et al., 2017). Bagian yang banyak dikonsumsi oleh masyarakat Indonesia adalah bijinya, yang dapat dimakan secara mentah ataupun dimasak menjadi keripik emping. Daun dan kulit buahnya juga seringkali dijadikan sebagai bahan sayuran (Lim, 2012). Melinjo yang memiliki banyak kegunaan ini disebabkan karena kandungannya yang terdiri dari protein $9-11 \%$, lemak $16,4 \%$, pati $58 \%$, serta fenol dan resveratrol (Kato et al., 2009). Menurut Hanan dan Sutrisno (2000), melinjo merupakan tanaman yang mengandung antioksidan tinggi sehingga mampu menghambat radikal bebas dan berfungsi sebagai antiaging. Aktivitas antioksidan disebabkan adanya senyawa fitokimia berupa alkaloid, flavonoid, saponin, dan tannin (Ira dan Ikhda, 2015).

Biji melinjo tersusun dari tiga lapisan pelindung, endosperma, dan embrio. Lapisan kulit luar biji berwarna hijau hingga merah. Perubahan warna kulit melinjo ini mengikuti tingkat kemasakan biji. Warna kulit berangsur- angsur berubah dari hijau, kuning, hingga merah. Terjadinya perubahan warna kulit luar biji melinjo dari hijau hingga menjadi merah disebabkan oleh adanya kandungan komponen fitokimia berupa pigmen (Cadiz and Florido, 2001).

Tiga lapisan pelindung yang dimiliki oleh biji melinjo merupakan karakteristik pembeda dengan spesies lain: Gnetum ula, Gnetum montanum, dan Gnetum neglectum yang memiliki dua lapisan pelindung. Ketiga lapisan pelindung biji melinjo memiliki berkas- berkas pengangkut, dimana pada kelompok Coniferales, kecuali Taxaceae, tidak memiliki berkas pengangkut pada integumennya. Sedangkan khusus di bagian lapisan tengah biji melinjo merupakan lapisan tersklerifikasi yang menyebabkan bagian tersebut bersifat kokoh dan keras (Rodin and Kapil, 1969). Lapisan kulit biji melindungi bagian endosperm sekaligus embrio biji yang akan mengalami diferensiasi.

Penelitian ini merupakan studi lanjutan dari penelitian sebelumnya yang membahas tentang karakter morfologis kulit luar biji melinjo (Nisa, 2017). Namun penelitian mengenai morfologi kulit tengah, kulit dalam, dan anatomis biji belum dibahas mendalam pada penelitian tersebut sehingga menjadi dasar dalam melakukan studi karakter dan perkembangan melinjo berdasarkan tingkat kemasakannya. Karakter morfologis dan perkembangan anatomis biji melinjo pada beberapa tingkat kemasakan akan dipaparkan dengan data ukuran biji dan gambar-gambar deskriptif.

Hasil dari penelitian ini diharapkan dapat menjadi sumber informasi ilmiah mengenai deskripsi karakter morfologis sekaligus anatomi biji melinjo yang sekaligus menjadi pendukung taksonomi tumbuhan Gymnospermae, khususnya pada ordo Gnetales dan genus Gnetum. Adanya deskripsi mengenai perkembangan anatomis biji, terutama pada embrio, merupakan studi awal mengenai struktur dan susunan biji melinjo. Maka penelitian ini dapat digunakan sebagai dasar dalam melakukan penelitian lebih lanjut mengenai perkembangan embrio biji melinjo yang mengalami penyimpangan atau anomali, yakni perkembangan poliembrioni ataupun polikotiledon, yang dikaitkan dengan karakter morfologis biji ataupun habitusnya.

Dari latar belakang tersebut, permasalahan yang muncul adalah bagaimana karakter morfologis dan struktur biji melinjo pada empat tingkat kemasakan biji. Maka tujuan dari penelitian ini adalah untuk mengetahui karakter morfologis dan struktur anatomis biji melinjo pada empat tingkat kemasakan biji. Hasil yang didapatkan dalam penelitian ini diharapkan dapat memberikan informasi ilmiah mengenai karakter morfologis dan struktur anatomis biji melinjo. 


\section{METODE PENELITIAN}

Penelitian dilakukan di Laboratorium Struktur Perkembangan Tumbuhan Fakultas Biologi UGM dengan menggunakan metode pembuatan preparat irisan organ tanaman tanpa penyelubungan parafin (non-embedding) berdasarkan penelitian Zulfadli et al. (2016), serta uji keberadaan amilum berdasarkan Musta et al. (2018).

Alat-alat yang digunakan adalah sebagai berikut: perolehan dan pengukuran sampel: galah, scale board, dan penggaris; pembuatan praparat anatomi biji: mikrotom geser Reichert, hot plate IKA C-MAG HS 7, gelas ukur, gelas benda, gelas penutup, cawan petri, silet, jarum preparat, dan pipet; observasi preparat dan pengukuran parameter anatomis: mikroskop cahaya dan OptiLab Advance Plus.

Bahan yang digunakan terdiri atas bahan tanaman dan bahan kimia. Bahan tanaman merupakan biji melinjo yang telah dipetik dari beberapa pohon di Kecamatan Mergangsang, Kota Yogyakarta, Provinsi Daerah Istimewa Yogyakarta selanjutnya dikelompokkan berdasarkan empat fase kemasakan berdasarkan Cadiz dan Florido (2001). Sedangkan bahan kimia yang diperlukan untuk pembuatan preparat anatomi biji antara lain larutan alkohol bertingkat hingga alkohol absolut (70\%, 80\%, 95\%, 100\%), alkohol/xilol 1:3, alkohol/xilol 1:1, alkohol/xilol 3:1, xilol, parafin, safranin 1\% dalam alkohol 70\%, dan balsam Canada. Pengujian keberadaan amilum menggunakan bahan kimia berupa larutan Iodine Potassium Iodide.

Cara kerja diawali dengan pengambilan dan pengukuran sampel. Biji melinjo diambil dari pohon melinjo yang berada di Kecamatan Mergangsan, Kota Yogyakarta, Provinsi Daerah Istimewa Yogyakarta, pada ketinggian 113 mdpl. Pengambilan sampel dilakukan pada bulan Oktober 2020 dimana pohon melinjo sedang dalam masa berbuah. Pengambilan sampel dilakukan dengan menggunakan galah. Biji melinjo yang diambil selanjutnya dibersihkan dan dikelompokkan menurut warna kulit buahnya. Biji melinjo dikupas kulit terluarnya dan dilakukan pengukuran panjang, lebar, dan diameter biji menggunakan scale board dan penggaris.

Selanjutnya struktur biji melinjo diamati melalui preparat anatomi yang disiapkan dengan metode pengirisan tanpa penyelubungan. Biji melinjo yang telah dipetik dari pohon kemudian dikupas bagian kulit terluarnya lalu dibersihkan. Sampel dimasukkan ke dalam larutan alkohol 70\% untuk melunakkan bahan dan bahan dapat diiris tanpa mudah pecah. Pengirisan bahan dilakukan dengan menggunakan mikrotom geser. Pengirisan sampel dilakukan secara melintang dan membujur dengan ketebalan 20-30 mikronmeter dan selanjutnya irisan ditampung dalam cawan petri berisi larutan alkohol $70 \%$. Irisan sampel tersebut diwarnai dengan pewarna safranin $1 \%$ dalam alkohol $70 \%$ lalu didiamkan selama 24 jam. Setelah 24 jam, larutan dibuang dan bahan berturut-turut dimasukkan ke larutan alkohol 70\%, 80\%,95\%, 100\%, alkohol/xilol (3:1, 1:1, 1:3), dan xilol masingmasing selama 10 menit. Setelah selesai dilakukan pencelupan, irisan diletakkan pada gelas benda dan ditutup dengan gelas penutup disertai pemberian balsam Canada. Preparat dikeringkan diatas hot plate dengan suhu $45^{\circ} \mathrm{C}$ hingga balsam Canada mengering.

Preparat anatomi kemudian dilakukan uji keberadaan amilum untuk melihat adanya kandungan amilum dalam biji. Biji yang telah dikupas kulitnya lalu dibersihkan dengan air bersih dan dihancurkan hingga mengeluarkan larutan putih. Sampel larutan diambil sebanyak $1 \mathrm{~mL}$ dan ditetesi dengan larutan iod 0,1 N. Warna biru yang dihasilkan menandakan adanya kandungan amilum.

Pengamatan dilakukan dengan mengamati morfologi biji secara langsung. Struktur anatomis diamati menggunakan mikroskop cahaya dan optilab. Bagian yang diamati terdiri atas: jaringan penyusun kulit biji, jaringan endosperm dan embrio pada empat fase kemasakan biji. 
Preparat anatomis biji diamati menggunakan mikroskop cahaya dilengkapi dengan OptiLab untuk pengambilan gambar dengan perbesaran mikroskop 4x10 dan 10x10. Parameter yang diamati adalah tebal jaringan penyusun sklerotesta, yakni jaringan parenkim, sklereida, dan sklerotesta secara keseluruhan. Pengukuran parameter dilakukan menggunakan aplikasi pendukung OptiLab berupa image raster dengan perbesaran bar $100 \mu \mathrm{m}$ dan bar $500 \mu \mathrm{m}$.

Data yang diperoleh disajikan dalam bentuk gambar seri dan tabel kemudian dianalisis secara kualitatif dan deskriptif. Data morfologi biji disajikan dalam tabel yang menampilkan ukuran dan gambar biji. Data preparat anatomi biji, yang terdiri dari hasil preparat anatomi biji disajikan dalam gambar seri dan tabel ukuran tebal kulit tengah biji, sementara hasil uji keberadaan amilum ditampilkan dalam bentuk gambar.

\section{HASIL DAN PEMBAHASAN}

\section{Morfologi Biji Melinjo (G. gnemon L.)}

Penelitian ini menggunakan biji melinjo pada beberapa tingkat kemasakan yang dilihat berdasarkan warna kulit luarnya. Biji melinjo yang digunakan sebagai sampel adalah biji yang telah berkembang. Pengamatan dilakukan dari bagian kulit tengah (sklerotesta) hingga ke bagian paling dalam atau embrio.

Sampel biji terlebih dahulu dilakukan preservasi atau metode penyimpanan dalam alkohol $70 \%$ supaya sel-selnya dapat terawetkan dan sampel dapat digunakan lebih lama. Pemilihan metode non-embedding karena kondisi biji relatif mengeras dan lebih mudah dilakukan pemotongan secara langsung tanpa merusak sampel. Preparat yang telah dipotong kemudian diberi pewarnaan berupa safranin dalam alkohol $70 \%$ karena mudah didapat, harga terjangkau, serta umum digunakan dalam pembuatan preparat awetan maupun segar.

Karakter morfologis pada biji melinjo dibedakan berdasarkan warna pada kulit biji. Biji melinjo fase pertama memiliki warna hijau muda dengan ukuran biji paling kecil diantara semua fase. Fase kedua mulai mengalami pematangan dimana warna kuning muda mulai muncul dan semakin mendominasi. Pada fase selanjutnya, warna biji berwarna kuning tua atau oranye, dan berubah menjadi merah. Warna merah tua ditemukan pada biji fase ke-3. Pada fase terakhir, warna biji menjadi merah kehitaman atau merah keunguan.

Biji berkembang dari ovulum yang memiliki jaringan parenkimatis berupa nuselus. Menurut Maheswari \& Vasil (1961), perkembangan awal ovulum dilindungi oleh lapisan integumen. Selanjutnya integumen terdiferensiasi menjadi periantium yang akan berkembang menjadi sarkotesta dengan struktur sel-sel yang berdaging, integumen luar yang berkembang menjadi sklerotesta dengan struktur sel yang keras dan berbatu, dan integumen dalam yang berkembang menjadi endotesta dimana strukturnya didominasi oleh jaringan jaringan parenkim.

Pada penelitian ini ditemukan beberapa fase biji melinjo berdasarkan tahap-tahap perkembangan dimana menunjukkan ukuran biji melinjo pada fase pertama hingga keempat dimana dilakukan pengupasan kulit biji terluar terlebih dahulu sehingga tampak bagian kulit tengah yang telah mengeras. Ukuran pada masing-masing fase secara umum tidak memiliki perbedaan yang jauh. Rentang ukuran panjang (p), lebar (1), dan diameter (d) biji melinjo berturut turut yakni antara $1,5 \mathrm{~cm}$ $-2,25 \mathrm{~cm} ; 1 \mathrm{~cm}-1,18 \mathrm{~cm}$; dan $1 \mathrm{~cm}-1,16 \mathrm{~cm}$. Biji yang semakin tua memiliki warna kulit biji yang lebih gelap yang dikarenakan oleh adanya penebalan sekunder dinding-dinding sel sklerenkim dan sklereid oleh lignin sehingga timbul warna gelap seiring kemasakan biji (Esse, 2018; Hartati, 2016). Ukuran dan warna biji melinjo secara rinci dapat diamati dalam Tabel 1 berikut ini. 
Tabel 1. Ukuran dan warna biji melinjo pada fase 1 hingga 4

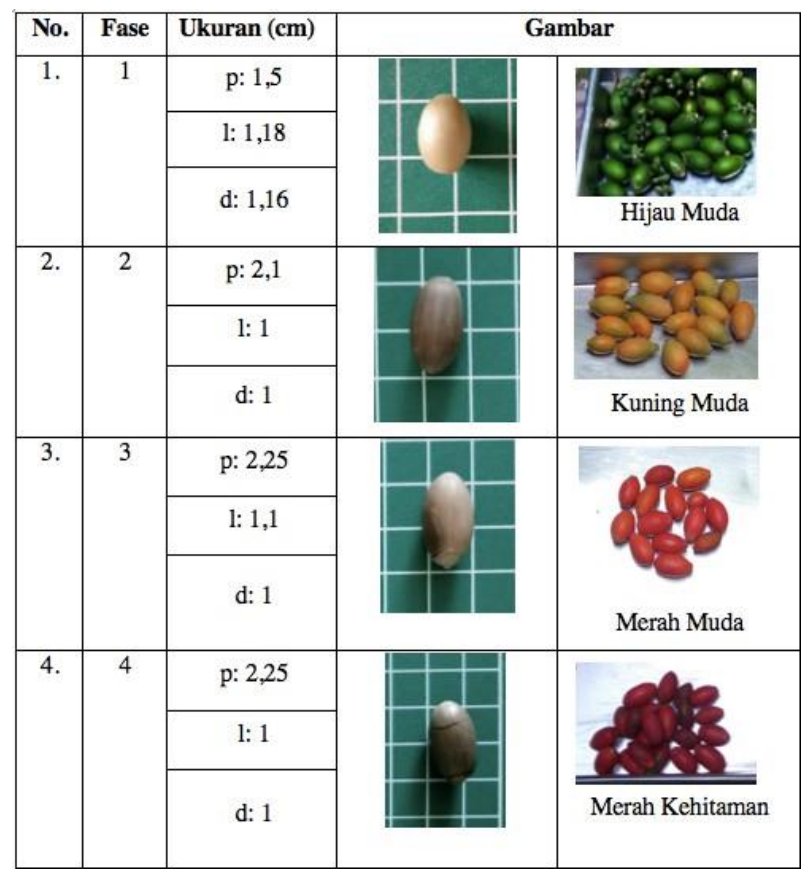

Biji dengan ukuran panjang paling kecil dimiliki oleh biji pada tingkat kemasakan paling muda serta ditunjukkan pula dengan kulit luar berwarna hijau. Namun berdasarkan ukuran lebar dan diameter biji tidak menunjukkan keterkaitan dengan tingkat kemasakan biji. Pada biji yang tua dapat memiliki lebar dan diameter lebih kecil dibandingkan dengan biji yang lebih muda. Hal tersebut dapat disebabkan oleh perbedaan proses perkembangan endospermnya. Sementara tingkat kemasakan biji dilihat berdasarkan warna kulit luarnya.

Maka kulit luar yang semakin masak juga dapat menunjukkan perkembangan biji. Warna kulit luar melinjo tersebut diakibatkan oleh adanya pigmen warna pada jaringan penyusunnya. Biji melinjo muda yang berwarna hijau disebabkan karena kandungan pigmen klorofil (Krautler, 2008). Pada perkembangan selanjutnya, kulit luar mengalami perubahan jenis pigmen yang diiringi oleh perubahan warna kulit luar menjadi kuning. Perubahan pigmen disebabkan oleh degradasi klorofil oleh enzim klorofilase sehingga terjadi peningkatan sintesis karotenoid yang ditampakkan dengan warna kuning pada kulit luar (Barry and Giovanonni, 2007). Perubahan warna kuning menjadi oranye pada tingkat kemasakan selanjutnya juga diakibatkan oleh pigmen karotenoid yang semakin banyak disintesis (Khoo et al., 2011) serta struktur kulit luar semakin lunak. Selanjutnya pada tingkat kemasakan akhir ditunjukkan dengan kulit luar berwarna merah hingga keunguan. Warna merah disebabkan karena pigmen karotenoid serta diiringi dengan adanya kandungan likopen pada biji (Syafaatur et al., 2015). 


\section{Anatomi Biji Melinjo (G. gnemon L.)}

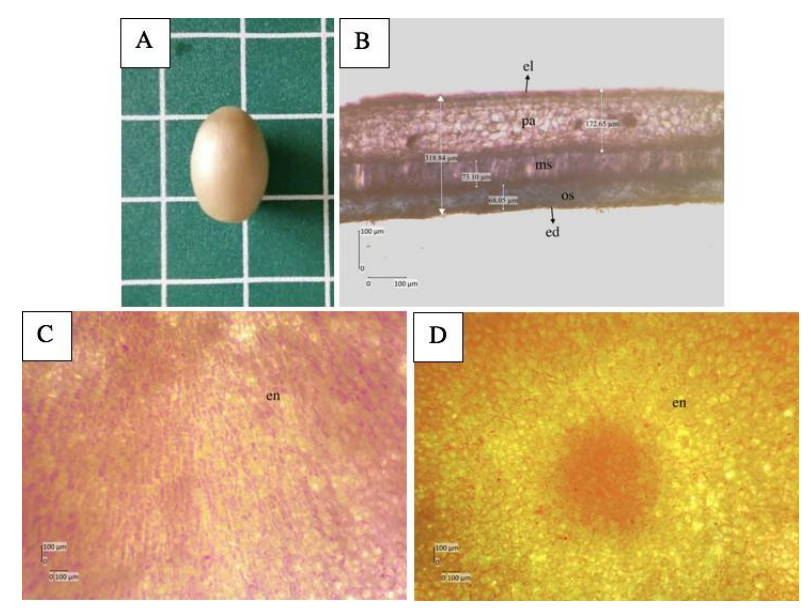

Gambar 1. Fase 1 Biji Melinjo (G. gnemon L.):

A. Biji, B. Penampang Melintang Kulit Biji Fase Satu, C. Penampang Bujur Endosperm, D. Penampang Lintang Endosperm.

Keterangan: sk: sklerotesta, el: epidermis luar, ed: epidermis dalam, os: osteosklereida, ms: makrosklereida, pa: parenkim, em: embrio, en: endosperm.

Pada gambar 1 menunjukkan kenampakan biji melinjo fase pertama, dimana kulit biji terlihat berwarna terang dan lunak (Gambar 1A). Bagian sklerotesta berkembang menjadi tiga lapis jaringan berupa jaringan epidermis, jaringan parenkim, jaringan sklereida (Gambar 1B). Lapisan epidermis terdiri atas satu lapis jaringan yang terletak di bagian paling luar dan paling dalam kulit biji. Jaringan epidermis tersusun rapat dan berbentuk rektangular (Gambar 1B, el, ed). Jaringan parenkim menyusun sebagian besar sklerotesta yang ditunjukkan dengan tebal lapisan hingga 172,65 $\mu \mathrm{m}$ (Tabel 2). Jaringan tersebut tersusun dari sel-sel yang berukuran besar, rapat, dan berbentuk poligonal (Gambar 1B, pa). Jaringan sklereida dapat dibedakan menjadi makrosklereida yang memiliki bentuk tiang, serta osteosklereida dengan bentuk tidak beraturan dan terpulas lebih gelap (Gambar 1B, ms, os). Lapisan sklereida belum berkembang secara sempurna karena belum mengalami penebalan maksimal. Bagian sklerotesta paling dalam adalah satu lapis epidermis dalam. Bagian dan struktur kulit biji akan berkembang terlihat lebih jelas pada fase berikutnya. Bagian endosperm tersusun dari jaringan parenkim yang tebal dan mengandung butir-butir amilum di dalamnya. Jaringan parenkin endosperm berbentuk poligonal dan tersusun rapat (Gambar 1C). Pada bagian embrio belum dapat dibedakan dengan jelas antara sel-sel jaringan endosperm. Pada Gambar 1C, bagian sentral biji terlihat memiliki susunan sel-sel yang lebih kompak dan memadat. Pada penampang bujur (Gambar 1D) bagian terpulas gelap di bagian tengah biji merupakan jaringan embrio pada perkembangan awal sehingga sel-selnya yang memiliki bentuk dan struktur seragam dengan jaringan endosperm. 


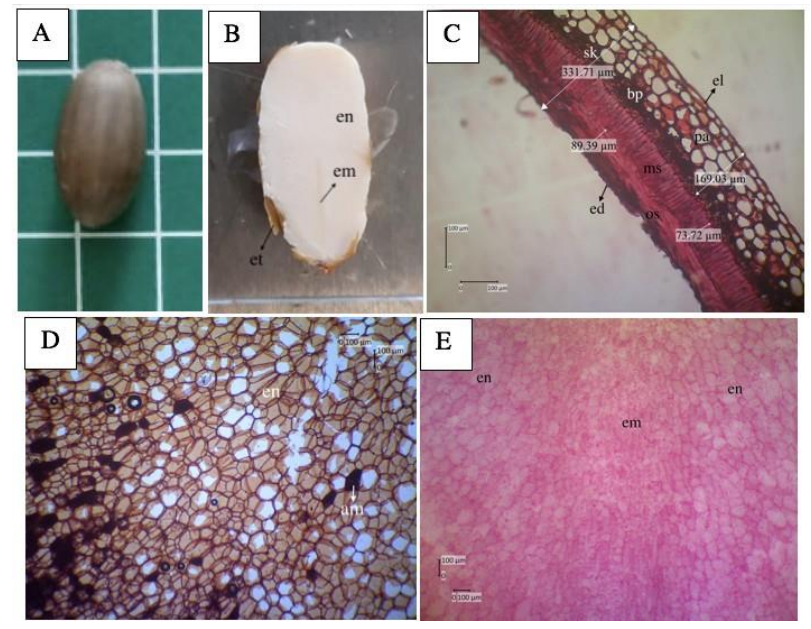

Gambar 2. Fase 2 Biji Melinjo (G. gnemon L.): A. Biji, B. Biji Tampak Bujur, C. Penampang Melintang Kulit Biji, D. Endosperm, E. Penampang Bujur Embrio.

Keterangan: sk: sklerotesta, et: endotesta, el: epidermis luar, ed: epidermis dalam, os: osteosklereida, ms: makrosklereida, pa: parenkim, bp: berkas pengangkut, em: embrio, en: endosperm

Gambar 2A merupakan morfologi biji pada fase kedua. Penyusun biji berturut-turut dari keluar ke dalam terdiri atas kulit biji, endosperm, dan embrio. Gambar 2B adalah biji yang dipotong secara membujur untuk melihat posisi embrio secara langsung, yakni bagian yang berwarna lebih gelap dan berbentuk pipih memanjang (Gambar 2B, em). Dapat teramati pula bagian endosperm dan kulit biji paling dalam (endotesta) secara morfologis (Gambar 2B, en, et). Kulit biji atau sklerotesta tersusun dari epidermis, jaringan parenkim, serta jaringan osteosklereida dan makrosklereida. Epidermis tersusun dari satu lapis sel yang berbentuk rectangular dan tidak memiliki ruang antar sel serta letaknya berada dilapisan paling luar dan paling dalam (Gambar 2C, el, ed). Sebelah dalam dari jaringan epidermis luar adalah jaringan parenkim yang memiliki sel-sel berukuran besar berbentuk poligonal dan tersusun rapat (Gambar 2C, pa). Bagian dalam dari jaringan parenkim merupakan jaringan sklerenkim yang terpulas lebih gelap, sel-selnya rapat, berukuran kecil, dan berbentuk poligonal. Jaringan sklerenkim terdiri atas zat lignin dan di dalamnya terdapat berkas pengangkut berupa xylem dan floem (Gambar 2C, bp). Lapisan selanjutnya adalah jaringan sklereida terdiri atas makrosklereida yang berbentuk tiang (Gambar 2C, ms) dan osteosklereida yang berbentuk serabut (Gambar 2C, os). Jaringan sklereida dilindungi oleh jaringan epidermis dalam yang terdiri atas satu lapis sel rektangular dan rapat (Gambar 2C, ed). Bagian jaringan endosperm tersusun dari sel-sel parenkim yang berbentuk poligonal, berukuran besar, dan tersusun rapat. Diantara jaringan parenkim endosperm terdapat sel-sel parenkim penimbun sebagai penyimpan zat amilum, dengan sel terpulas hitam, berbentuk poligonal, dan letaknya tersebar pada endosperm (Gambar 2D, am). Jaringan embrio teramati secara membujur, dimana sel-sel embrio memiliki sel yang lebih kecil, rapat, dan berbentuk isodiametris (Gambar 2E, em).

Fase 2 perkembangan biji melinjo merupakan biji dengan warna kulit luar didominasi warna kuning dibanding warna hijau. Gambar hasil diatas menunjukkan bahwa kulit biji fase 2 mengalami penebalan menjadi 331,71 $\mu \mathrm{m}$. Penebalan kulit biji disebabkan karena jaringan penyusunnya yang menebal, terutama pada jaringan penguat berupa sklerenkim yang terdiri atas jaringan fiber dan 
sklereida. Jaringan sklerenkim memiliki sel-sel berdinding sekunder terlignifikasi dan akan berhenti berkembang ketika dewasa. Senyawa lignin berperan dalam pembentukan dinding sel sekunder pada tanaman vaskuler. Dinding sekunder tersebut disekresikan setelah pembentukan dinding primer dan terletak di bagian dalam dinding primer. Penebalan dinding oleh senyawa lignin menghasilkan lubang atau lumen di bagian tengah sel sehingga selnya berbentuk seperti lingkaran (Simpson, 2019).

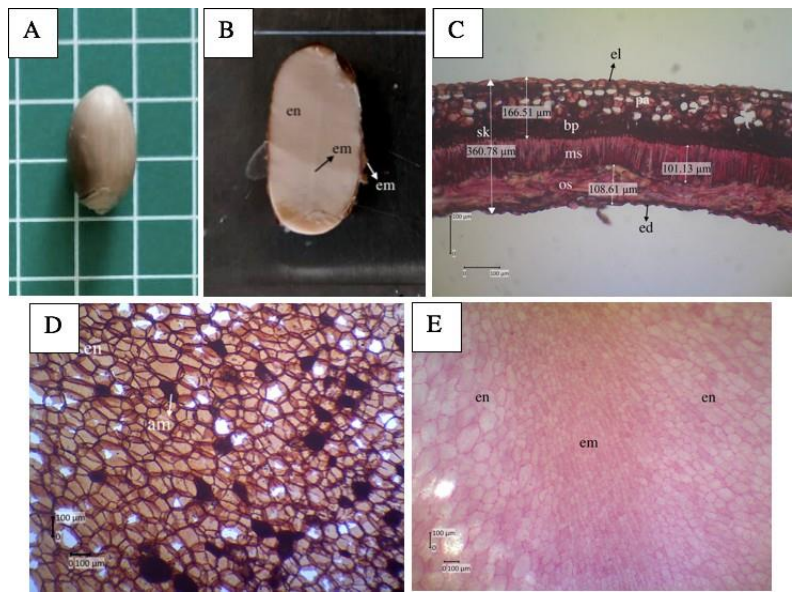

Gambar 3. Fase 3 Biji Melinjo (G. gnemon L.):

A. Biji, B. Biji Tampak Bujur, C. Penampang Melintang Kulit Biji, D. Endosperm, E. Penampang Bujur Embrio.

Keterangan: sk: sklerotesta, et: endotesta, el: epidermis luar, ed: epidermis dalam, os: osteosklereida, ms: makrosklereida, pa: parenkim, bp: berkas pengangkut, em: embrio, en: endosperm.

Fase ketiga perkembangan biji melinjo dapat teramati kenampakannya pada Gambar 3A. Pada fase ini posisi embrio dapat terlihat pada biji yang dipotong membujur, yakni bagian yang terpulas lebih terang dan lebih memanjang dibanding fase sebelumnya (Gambar 3B, em). Bagian sklerotesta tampak lebih tebal dibanding fase kedua (Gambar 2C), dimana jaringan sklerenkim beserta berkas pengangkut lebih jelas dan lebih tebal (Gambar 3B, bp), serta jaringan sklereida yang tampak menebal (Gambar 3C, ms, os). Bagian parenkim penimbun pada jaringan endosperm tampak tersebar dan lebih banyak sehingga dapat teramati dengan jelas (Gambar 3D, am). Pada gambar $3 \mathrm{E}$ teramati pula jaringan embrio yang tampak berbeda dengan jaringan endosperm disekitarnya. Gambar 3E tersebut merupakan embrio di zona mikropil. Fase tiga dari perkembangan biji melinjo merupakan biji dengan warna merah muda. Ukuran biji semakin besar, dimana endospermnya semakin berkembang pesat (Tabel 1). Susunan embrio secara utuh teramati pada Gambar 4G, dimana sel-selnya memadat ke bagian tengah biji dan memanjang hingga ke zona khalaza. Dapat teramati pula pada zona khalaza sel-sel embrio tersusun repih dan tidak sepadat jaringan diatasnya sehingga terbentuk bagian seperti rongga (Gambar 4G, kh). Namun pada fase ini diferensiasi jaringan embrio sudah tambak lebih jelas menjadi epikotil, hipokotil, dan kotiledon. 


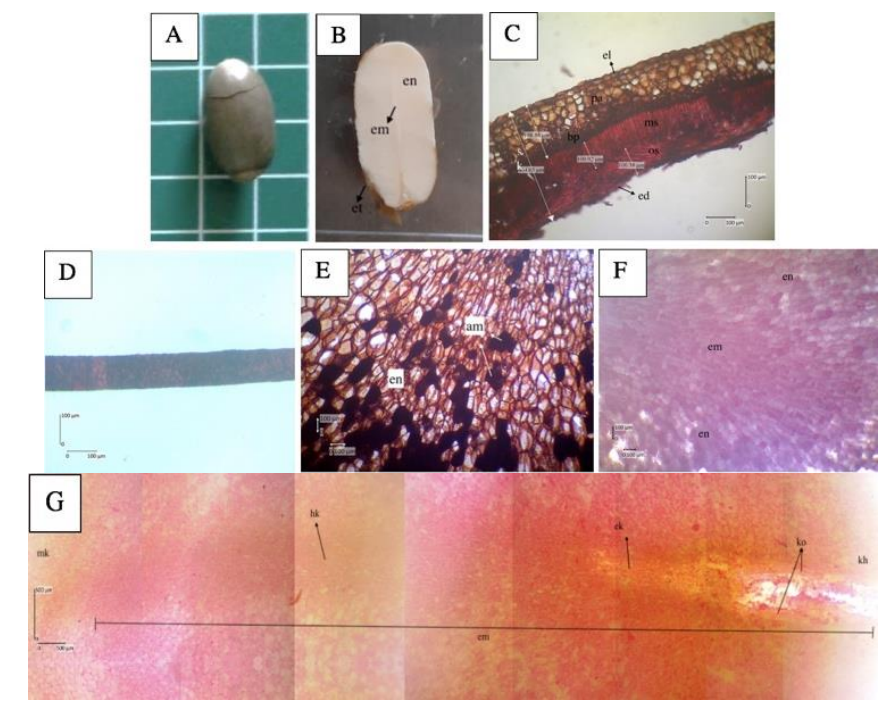

Gambar 4. Fase 4 Biji Melinjo (G. gnemon L.): A. Biji, B. Biji Tampak Bujur, C. Sklerotesta, D. Endotesta, E. Endosperm, F. Penampang Bujur Embrio, G. Penampang Utuh Embrio Secara Bujur.

Keterangan: sk: sklerotesta, et: endotesta, el: epidermis luar, ed: epidermis dalam, os: osteosklereida, ms: makrosklereida, pa: parenkim, bp: berkas pengangkut, em: embrio, en: endosperm, mk: mikropil, kh: khalaza, hk: hipokotil, ek: epikotil, ko, kotiledon

Gambar 4 menunjukkan fase perkembangan biji paling matang dibanding fase-fase sebelumnya karena memiliki kulit biji berwarna merah kehitaman. Dapat teramati kenampakan biji fase empat secara morfologis (Gambar 4A). Posisi embrio pada biji terpulas lebih terang dibanding jaringan endosperm, serta berbentuk pipih memanjang hingga bagian apikal biji (Gambar 4B, em). Jaringan sklerotesta yang tampak paling tebal adalah makrosklereida dan osteosklereida (Gambar 4C, sk, ms, os; Tabel 2). Susunan endotesta pada fase ini tampak jaringan parenkimatis. Namun menurut Takaso dan Bouman (1986), jaringan endotesta juga disertai dengan jaringan sklereida yang memanjang (Gambar 4D, et). Jaringan endosperm pada Gambar 4E sel-selnya berukuran lebih besar dan kompak (en). Jaringan parenkim penimbun tampak lebih banyak, yakni sel-sel yang terpulas hitam dan tersebar di bagian endosperm (Gambar 4E, am). Jaringan embrio yang teramati memiliki sel-sel lebih besar serta tersusun lebih kompak, padat, dan rapat dibanding jaringan parenkim endosperm disekitarnya. Jaringan Embrio yang terlihat merupakan embrio pada zona mikropil.

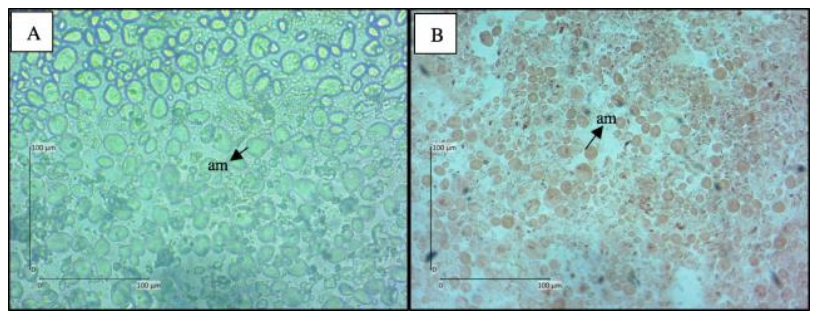

Gambar 5. Amilum Melinjo (G. gnemon L.) pada fase 3: A. Amilum tanpa perlakuan, B. Amilum dengan perlakuan.

Keterangan: am: amilum 
Gambar 5 menunjukkan sel-sel yang menyimpan amilum dalam jaringan endosperm. Keberadaan amilum dibuktikan dengan sel-sel yang berubah warna ketika diberi perlakuan berupa Iodine Potassium Iodida menjadi coklat kemerahan yang menandakan adanya kandungan glikogen dan dekstrin (Gambar 5B). Amilum pada G. gnemon yang berbentuk poligonal dan lemping (flakeshape) merupakan amilum primer, dimana tidak terdapat hilum serta tidak terdapat garis lamella (Gambar 5), serta terbentuk dalam sel amiloplas.

Uji iodine menggunakan larutan Iodine Potassium Iodida merupakan salah satu metode pengujian untuk membedakan karbohidrat yang terdiri atas dua jenis polisakarida yang berbeda, yakni monosakarida dan disakarida (Musta, 2018). Perubahan warna yang terjadi pada larutan JKJ diakibatkan karena adanya reaksi antara larutan JKJ dengan rantai heliks unit-unit glukosa. Zat amilum mampu bereaksi dengan larutan uji membentuk warna berbeda karena molekul yodium masuk ke dalam spiral heliks dan membentuk kompleks warna tertentu. Prinsip pada pengujian iodine yakni karbohidrat golongan polisakarida akan memberikan reaksi berbeda dan spesifik bergantung pada jenis karbohidratnya. Larutan iodin yang direaksikan dengan glikogen akan membentuk warna merah sampai cokelat yang disebabkan karena adanya penyerapan iodin pada struktur cincin glikogen yang saling berikatan sehingga membentuk komples berwarna merah kecoklatan. Amilosa dan iodin akan berwarna biru, amilopektin dengan iodin akan berwarna merah violet, dekstrin dengan iodin akan berwarna merah coklat (Mustakin dan Tahir, 2019).

Karbohidrat yang banyak ditemukan dalam tanaman sebagai amilum merupakan sumber karbon dan energi bagi perkembangan tanaman (Smith, 2001). Amilum dibentuk di dalam kloroplas daun serta dibentuk di bagian amiloplas yang berperan penting dalam sintesis amilum pada tanaman sereal dan umbi-umbian (Smith, 2001; Tester et al., 2004). Secara morfologi, butir amilum berdiameter 0,1 hingga $200 \mu \mathrm{m}$ dan memiliki bentuk yang bervariasi seperti oval, ellipsoid, membulat, angular, dan lenticular bergantung pada jenis tanamannya (Buléon et al., 1998; Hoover, 2001; Singh et al., 2003). memiliki banyak sel-sel penyimpan amilum serta sel-sel dengan saluran sederhana penyimpan minyak (Biswas and Johri, 1997).

Kulit biji melinjo pada masing-masing fase memiliki tingkat ketebalan yang berbeda yang dipengaruhi oleh tingkat kemasakannya. Ketebalan sklerotesta beserta jaringan penyusunannya telah diukur dan disajikan dalam Tabel 2.

Tabel 2. Ukuran Sklerotesta pada Penampang Lintang Kulit Biji Melinjo (G. gnemon L.

\begin{tabular}{|c|c|c|c|c|}
\hline Fase & $\begin{array}{c}\text { Sklerotesta } \\
(\mu \mathbf{m})\end{array}$ & $\begin{array}{c}\text { Parenkim } \\
(\mu \mathbf{m})\end{array}$ & $\begin{array}{c}\text { Makrosklereida } \\
(\mu \mathbf{m})\end{array}$ & $\begin{array}{c}\text { Osteosklereida } \\
(\mu \mathbf{m})\end{array}$ \\
\hline $\mathbf{1}$ & 318,84 & 172,65 & 73,10 & 68,05 \\
\hline $\mathbf{2}$ & 331,71 & 169,03 & 73,72 & 89,39 \\
\hline $\mathbf{3}$ & 360,78 & 166,51 & 101,13 & 108,61 \\
\hline $\mathbf{4}$ & 397,29 & 186,05 & 107,19 & 115,74 \\
\hline
\end{tabular}

Yasui (1948) menyebutkan bahwa sebagian besar butir amilum tersusun dari kristal amilum yang disintesis di amiloplas. Amilum dapat dibedakan menjadi dua jenis, yakni amilum primer dan amilum sekunder. Amilum primer dapat disebut dengan amilum sederhana atau amilum sejati. Produksi amilum yang terjadi di dalam vakuola amiloplas menghasilkan amilum dengan membran plasma berukuran kecil dan berdinding tebal yang kemudian disebut sebagai amilum tahap akhir perkembangan. Maka tidak terdapat hilus dan lamella sebagai penanda awal perkembangan karena 
hanya sekali terjadinya pemadatan isi vakuola. Sementara itu, amilum sekunder dicirikan dengan amilum yang memiliki titik awal perkembangan amilum yang disebut dengan hilum. Terjadinya lapisan sekat lamella diakibatkan karena letak molekul yang lebih padat di awal pembentukan lapisan. Selanjutnya molekul menjadi lebih renggang secara bertahap sehingga terdapat perbedaan kadar air yang terkandung di dalam vakuola amilum tersebut (Kumalawati et al., 2018).

Pada G. gnemon L., aktivitas meristematik paling tinggi terjadi di bagian poros gametofit sehingga pembentukan endosperm sangat pesat di bagian tengah biji. Perkembangan endosperm juga diiringi dengan pembentukan butir amilum dimana berturut- turut muncul pada lapisan sel luar, lapisan mikropil, hingga sel-sel poros. Biji dewasa Berdasarkan Tabel 2 tersebut, dapat diketahui tebal jaringan pada kulit biji atau sklerotesta G. gnemon L. di setiap fase perkembangan. Kulit biji yang semakin berkembang akan memiliki lapisan sklerotesta yang semakin tebal dan disertai pula dengan penebalan jaringan-jaringan penyusunnya. Kulit biji fase satu memiliki lapisan sklerotesta paling tipis yakni $318,84 \mu \mathrm{m}$, tetapi memiliki jaringan parenkim dan makrosklereida yang lebih tebal dibandingkan kulit biji fase selanjutnya yakni berturut turut $172,65 \mu \mathrm{m}$ dan $73,10 \mu \mathrm{m}$. Kulit biji paling tebal dimiliki oleh biji fase 4 dimana keseluruhan bagian setebal 397,29 $\mu \mathrm{m}$ dengan jaringan parenkim 186,05 $\mu \mathrm{m}$, makrosklereida $107,19 \mu \mathrm{m}$, dan osteoklereida $115,74 \mu \mathrm{m}$.

Fase pertama memiliki lapisan paling tipis dan lunak karena belum mengalami perkembangan yang maksimal. Hal tersebut ditunjukkan dengan jaringan sklereida yang belum mengalami elongasi sementara sebagian besar lapisan kulit biji tersusun dari jaringan parenkim meristematis. Jaringan yang teramati paling tebal pada setiap fase adalah jaringan sklereida, yakni jaringan makrosklereida dan osteosklereida, karena merupakan jaringan penguat yang melindungi jaringan nutritif di dalamnya. Sementara jaringan parenkim juga mengalami penebalan signifikan karena merupakan jaringan dasar yang berperan sebagai berkas pengangkut.

\section{KESIMPULAN}

Karakter morfologis berdasarkan ukuran dan warna biji pada empat tahap pemasakan biji mengalami peningkatan. Kulit luar biji fase 1 memiliki warna hijau hingga merah kehitaman pada fase 4 . Sementara kulit biji tengah berwarna coklat muda pada fase 1 hingga semakin gelap pada fase 4. Ukuran biji semakin meningkat: panjang biji $\pm 1,5 \mathrm{~cm}$ pada fase paling awal hingga mencapai $\pm 2,25 \mathrm{~cm}$ pada tahap akhir; lebar biji antara $1 \mathrm{~cm}-1,18 \mathrm{~cm}$; diameter biji antara $1 \mathrm{~cm}-1,16 \mathrm{~cm}$. Struktur anatomis biji melinjo pada tiap tingkat kemasakan biji mengalami penebalan kulit tengah dan diferensiasi struktur jaringan embrio. Jaringan penyusun kulit biji bagian tengah dari fase pertama hingga terakhir semakin menebal, yakni pada fase pertama sebesar $318,84 \mu \mathrm{m}$ hingga pada fase terakhir sebesar 397,29 $\mu \mathrm{m}$. Sel-sel jaringan endosperm mengalami pemadatan sel seiring pemasakan biji. Diferensiasi jaringan embrio membentuk hipokotil, epikotil, dan kotiledon.

\section{DAFTAR PUSTAKA}

Barry, C. S. and J. J. Giovannoni. 2007. Ethylene and Fruit Ripening. J. Plant Growth Regulation, $26,143-159$.

Biswas, C. and B. M. Johri. 1997. The Gymnosperms. New Delhi: Narosa Publishing House.

Buléon, A., Colonna, P., Planchot, V., and Ball,

S. 1998. Starch granules: structure and biosynthesis. International Journal of Biological Macromolecules, 23 (2), 85- 112. 
Cadiz, R. T. and H. B. Florido. 2001. Bago, Gnetum gnemon Linn. Research Information Series on Ecosystems, 13 (2), 1-6.

Hoover, R. 2010. The impact of heat-moisture treatment on molecular structures and properties of starches isolated from different botanical sources. Critical Reviews in Food Science and Nutrition, 50 (9), 835-847.

Kato, E., Y. Tokunaga, and F. Sakan. 2009. Stilbenoids isolated from the seeds of melinjo (Gnetum gnemon) and their biological activity. J. Agric. Food Chem, 57 (6), 2544-2549.

Khoo, H., K. N. Prasad, K. W. Kong, Y. Jiang, and A. Ismail. 2011. Carotenoids and Their Isomer: Color Pigments in Fruits and Vegetables. J. Molecules, 16, 1710 - 1738.

Krautler, B. 2008. Chlorophyll Breakdown and Chlorophyll Catabolites in Leaves and Fruit. Photochem Photobiol Sci, 7 (3), $154-165$.

Kumalawati, H., M. Izzati, dan S. W. A. Suedy. 2018. Bentuk, Tipe, dan Ukuran Amilum Umbi Gadung, Gembili, Uwi Ungu, Porang, dan Rimpang Ganyong. Buletin Anatomi dan Fisiologi, 3 (1), 56 - 61.

Lim, T. K. 2012. Edible Medicinal and Non-Medicinal Plants. New York: Springer.

Maheshwari, P. A. and D. V. Vasil. 1961. Gnetum Bot. Monogr. No. 1. New Delhi: Council Sci. Industr. Res.

Musta, R. 2018. Waktu Optimum Hidrolisis Pati Limbah Hasil Olahan Ubi Kayu (Manihot esculenta Crantz var. Lahumbu) Menjadi Gula Cair Menggunakan Enzim $\alpha$-Amilase Dan Glukoamilase. Indonesian Journal of Chemical Research, 5 (2), 498-507.

Mustakin, F. Dan M. M. Tahir. 2019. Analisis Kandungan Glikogen pada Hati, Otot, dan Otak Hewan. Cenrea Journal, 2 (2), 75 - 80.

Nisa, R. I. 2017. Struktur Anatomis dan Profil Fitokimia Kulit Luar Biji Melinjo (Gnetum gnemon L.) pada Empat Tingkat Kemasakan Biji. Skripsi. Program Sarjana Universitas Gadjah Mada, Yogyakarta.

Rodin, R. J. And R. N. Kapil. 1969. Comparative Anatomy of the Seed Coats of Gnetum and Their Probable Evolution. American Journal of Botany, 56 (4), 420 - 431.

Simpson, M. G. 2019. Plant Systematics: Third Edition. Oxford: Academic Press.

Singh, N., Singh, J., Kaur, L., Sodhi, N. S., and Gill, B. S. 2003. Morphological, thermal and rheological properties of starches from different botanical sources. Food Chemistry, 81 (2), 219-231.

Smith, A. M. 2001. The biosynthesis of starch granules. Biomacromolecules, 2 (2), 335 $-341$.

Syafaatur, N. R., R. Panji, and I. N. Cikra. 2015. Perbandingan kadar likopen pada Manilkara zapota L., Gnetum gnemon L., Ipomoea batatas L., dan Momordica charantia L., dengan menggunakan campuran solven n-heksan, aseton, dan etanol. Jurnal Farmasi Sains dan Terapan, 2 (1), 8 - 11 .

Takaso, T. and F. Bouman. 1986. Ovule and Seed Ontogeny in Gnetum gnemon L. The Botanical Magazine, 99, 241 - 226.

Tester, R. F., Karkalas, J., and Qi, X. 2004. Starch - Composition, fine structure and architecture. Journal of Cereal Science, 39 (2), 151-165.

Yasui, K. 1948. On the Structure and the Development of Starch Grains. Cytologia, 15, 75 - 87.

Zulfadli, N. Wijayanti, B. Retnoaji. 2016. Perkembangan Ovarium Ikan Wader Pari (Rasbora lateristriata Bleeker, 1854): Pendekatan Histologi. Jurnal Perikanan Tropis, 3 (1), 32-38. 